\title{
Physiological, immunological and genetic factors in the resistance and susceptibility to gastrointestinal nematodes of sheep in the peripartum period: A review
}

\author{
R. GONZÁLEZ-GARDUÑO1', J. ARECE-GARCÍA², G. TORRES-HERNÁNDEZ ${ }^{3, *}$
}

\begin{abstract}
${ }^{1}$ Universidad Autónoma Chapingo. Unidad Regional Universitaria Sursureste. Teapa, Tabasco. MÉXICO; ${ }^{2}$ Estación Experimental de Pastos y Forrajes "Indio Hatuey". Universidad de Matanzas. Matanzas. CUBA; ${ }^{3}$ Colegio de Postgraduados-Campus Montecillo. 56230 Montecillo, Estado de México. MÉXICO, E-mail: glatohe@colpos.mx
\end{abstract}

Article info

Received September 9, 2020

Accepted February 10, 2021

\begin{abstract}
Summary
Parasitic diseases of sheep involving gastrointestinal nematodes (GIN) are one of the main problems that affect flock productivity, especially during the peripartum period. Around lambing, the ewes are immunosuppressed and the nematode faecal egg count (FEC) increases at four weeks before lambing, reaching a peak between the fourth and sixth week postpartum and subsequently decreasing towards weaning. Prolactin has been credited with a suppressive effect on immune system, along with other hormones that intervene in metabolism, such as leptin, which has an important role in the activation of other hormones. Cortisol has also been included; this is stimulated by any stressful event and inhibits the proliferation of T-cells and alters the function of immunoglobulins. Another related hormone is pepsinogen, which is considered a marker of the integrity of the abomasum mucosa, as well as the albumin concentration that increases in the presence of a GIN infection. The humoral and cellular immune response, as well as inflammatory reactions, are the main mechanisms of action against GIN. Lymphocytes direct the effector mechanisms in a Th2 cell response, including interleukins (IL-4, IL-5, IL-9, IL-10) and transforming growth factor beta (TGF- $\beta$ ) together with immunoglobulins ( $\lg A$, $\lg G$, $\lg M$ and $\lg E$ ), which prevent the invasion of pathogens. Eosinophils with a cytotoxic effect are indicators of a parasitic infection, with importance in the immune protection of infected individuals. The genetic selection of resistant individuals measured by FEC is dependent on the heritability $\left(h^{2}\right)$, which is moderately inheritable and highly repeatable. Effects that influence the resistance or susceptibility of sheep to GIN infections in the peripartum period are determined by the interaction of various factors, such as genotype or breed, nutrition, age, type of birth, season and production system, etc., which are studied in this review.
\end{abstract}

Keywords: cellular immunity; humoral immunity; infection; nematode parasites; peripartum rise

\section{Introduction}

Gastrointestinal nematode (GIN) infections are one of the main parasitic diseases that affect small ruminants around the world (Torres-Acosta \& Hoste, 2008), causing physiological and productive alterations. Much work has been done in the search for control alternatives that minimise the consequences of parasitism that have an impact on the productive efficiency of flocks, particularly under grazing conditions (Mugambi et al., 2005; Vázquez-Hernández et al., 2006; Karrow et al., 2014) with emphasis on young lambs and ewes during the peripartum period (Kahn et al., 1999), when the problems of parasitism are accentuated by the increased fae-

\footnotetext{
$\overline{\text { * - corresponding author }}$
} 
cal egg count (FEC) of ewes that are responsible for contributing to the contamination of the grazing area with GIN eggs (Beasley et al., 2010), in turn constituting a source of infection for suckling lambs (Ng'ang'a et al., 2004). In this period, immunosuppression occurs in sheep and goats, with interaction between physiological, immunological, nutritional and genetic factors, among others, which makes them susceptible to other infections.

From the immunological point of view, sheep with resistance to GIN are those that have the capacity to produce a greater number of cytokines derived from the Th2 response, related mainly to the reduced expulsion of eggs and the elimination of worms (Hayward, 2013). This being associated with high levels of $\lg E$ and eosinophils (Muñoz-Guzmán et al., 2006; Sayers et al., 2007; Lalramhluna et al., 2020), and high concentrations of IgA, IgG and IgM, with strong local immunity, effective in limiting the establishment and/or eliminating the worm population (Beasley et al., 2010; Albuquerque et al., 2019). This answer is very important and there are reviews of immunoglobulins associated with resistance in sheep to GIN (Aboshady et al., 2020). However, in goats appear to lack a functional $\lg A$ and eosinophil response against natural nematode infection (Basripuzi et al., 2018). Susceptible animals present a reduction in the counts of lymphocytes, leukocytes, mast cells and eosinophils in the abomasum mucosa, as well as a reduction in the concentration of $\lg G, \lg E$, $\lg M$ and $\lg A$, facilitating the invasion of pathogens (O'Sullivan \& Donald, 1973; Beasley et al., 2010; Albuquerque et al., 2019). On the other hand, the identification of genes for resistance to infectious diseases is based mainly on the search in DNA or in chromosomal regions for related loci; when these are identified, it would be possible to select resistant sheep within a population (Stear \& Murray, 1994; Houdijk, 2008; Zvinorova et al., 2016). By developing resistant genotypes, associated with adequate feed consumption and balanced feeding, particularly in the peripartum period, an improvement in the immune response capacity of sheep will occur (Valderrábano et al., 2006; Kidane et al., 2010; Jones et al., 2012; Beasley et al., 2012; Werne et al., 2013), coupled with better development of the mammary gland and milk production during lactation. The purpose of this document is to review some physiological, immunological and genetic foundations, as well as certain factors that intervene in the expression and variability of resistance of sheep to GIN in the peripartum period.

\section{Material and Methods}

This review was carried out with the aid of the Elsevier platform (Scopus and ScienceDirect) and the Google Scholar, Redalyc, and Scielo Services. A total of 161 documents, like papers, theses, books, and meta-analyses, were consulted. The manuscripts were related to topics that revealed evidence about physiological, immunological and genetic factors related with the resistance and susceptibility to gastrointestinal nematodes of sheep in the peripartum period.

\section{Ethical Approval and/or Informed Consent}

This article does not contain any studies with human participants or animals by any of the authors.

\section{Results and Discussion}

\section{Periparturient relaxation of immunity (PPRI)}

The peripartum relaxation of immunity happens when the circulating eosinophils and plasma antibodies decrease and remain low at end of pregnancy and during lactation in ewes. At local level, lower titers of antibodies (IgG1, IgM, IgA and $\lg E$ ) as well as few cell counts (globule leucocytes, mast and goblet cells) in intestinal tissue (Beasley et al., 2010).

There is a transitory increase in the excretion of eggs in the faeces, especially during the last third of pregnancy and the first weeks of lactation (Hamer et al., 2019). This phenomenon has been widely studied in small ruminants, particularly in sheep, and is known as postpartum rise, lactation rise or peripartum rise (PPR) (Houdijk, 2008; Torres-Acosta \& Hoste, 2008; Kidane et al., 2010; Goldberg et al., 2012a; Fthenakis et al., 2015). In ewes, the number of eggs per gram (EPG) excreted in faeces increases from four weeks before lambing, reaching a peak between the fourth and sixth week postpartum (Courtney et al., 1985; Goldberg et al., 2012a), subsequently decreasing towards the time of weaning (Vázquez-Hernández et al., 2006). The rise in the egg excretion rate in faeces is associated with the increase in the fertility of the parasitic females as a result of a group of immunological factors being depressed in the peripartum period. This event may be accompanied by clinical signs due to the effect of gastrointestinal parasitism (Ng'ang'a et al., 2004; Werne et al., 2013). Increased susceptibility to other infections may also occur during this period ( $\mathrm{Ng}^{\prime}$ ang'a et al., 2004; Karrow et al., 2014), especially in ewes with high susceptibility to GIN due to high variability within breed (Gonçalves et al., 2018).

\section{Physiological foundation of resistance in peripartum}

In PPR, temporary alterations are characterised by physiological and metabolic changes associated to pregnancy and lactation (Ahmed et al., 2020). These changes also occur in cells and proteins of the immune system, that result in a low response of sheep against any infection, particularly those caused by GIN ( Gibbs \& Barger, 1986; Barger, 1993; Kahn et al., 1999; Goldberg et al., 2012b; Jonsson et al., 2013; Pereira et al., 2020). The modulation of immune system is associated with disturbances in the endocrine system (Tembely et al., 1998; Beasley et al., 2010; Jonsson et al., 2013). Physiologically, it has been indicated that oestrogens stimulate the cellular and humoral immune responses by inducing direct effects on multiple cell types including immune and vascular cells (Trenti et al., 2018). In addition, in the peripartum period lactogenic hormones abound in the circulation and are antagonistic to oestrogens (Barger, 1993). Nutritional aspects (Jones et al., 


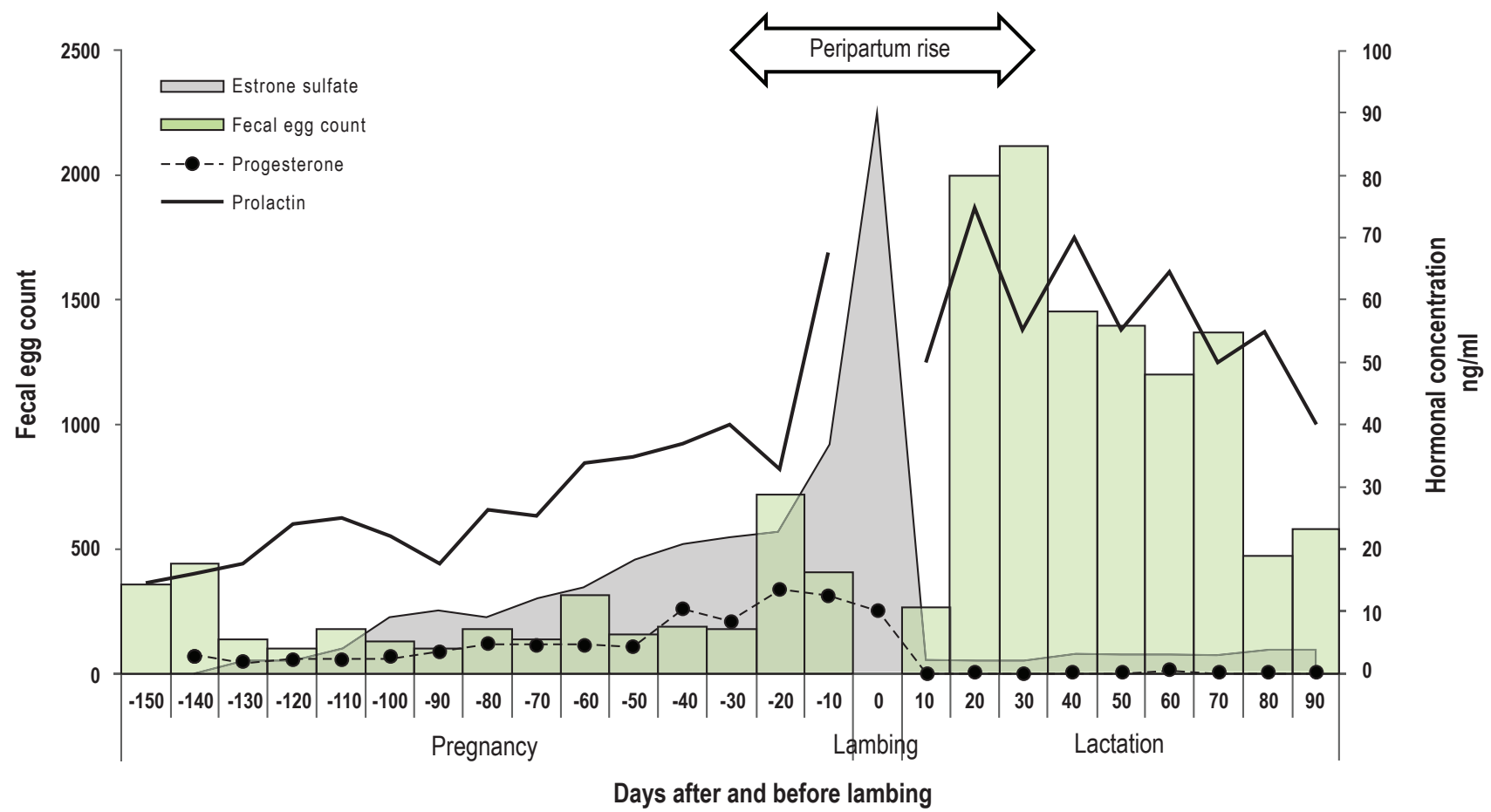

Fig. 1. Interaction of estrogenic and lactogenic hormones and nematode faecal egg count in the pregnancy and lactation of hair ewes. Elaborated with the information of several authors (Kann and Denamur, 1973; Convey, 1974; Ranilla et al., 1994; González-Garduño et al., 2014; Miura et al., 2019).

2012), genetic influences (Kidane et al., 2010) and stress triggers also play important roles (Tembely et al., 1998). During the immediate prepartum period serum estrogens and estrone increase markedly. At partum withdrawal of progesterone the estrogens removes the block to lactation, and milk secretion results. Estrogen steroid decreased rapidly to low levels immediately postpartum and the release of growth hormone at parturition is required for normal lactation in ruminants (Convey, 1974) together with high levels of prolactin (Phillipps et al., 2020), as observed in Figure 1.

\section{Prolactin}

Prolactin is responsible for initiating and maintaining lactation, with a stimulating effect by the suckling lambs (Fthenakis et al., 2015). It has a suppressive effect on the host's immune system, by reducing the IgA levels necessary to prevent parasitic establishment at the intestinal level (Torres-Acosta \& Rodríguez-Vivas, 1995; Kahn et al., 1999; Houdijk, 2008), favouring growth of the nematodes and the fertility of the female worms. The increased levels of prolactin at lambing coincides with low number of circulating eosinophils and by decreased total antibody and $\lg \mathrm{G} 1 \mathrm{ti}-$ ters (Fthenakis et al., 2015). Progesterone, the principal steroidal regulator of pregnancy, also has several immunosuppressive activities. However, in ovariectomized sheep, prolactin alone had a greater effect on the reduction of FEC (Fleming \& Conrad, 1989). Although prolactin together with progesterone reduces the num- ber of cells such as eosinophils, but in pregnancy the FEC are not high, suggesting that other mechanism and hormones are involved (Torres-Acosta \& Rodríguez-Vivas, 1995; Kahn et al., 1999; Houdijk, 2008; Beasley et al., 2010; Fthenakis et al., 2015). The results show that Haemonchus contortus larvae have possible receptors to progesterone and respond to progesterone by inhibiting their moulting and, in consequence, their development. These results suggest that progesterone participates in larval arrest (Gutiérrez-Amézquita et al., 2017). In pregnant Angora goats, a high EPG value is associated with a high concentration of prolactin, compared to non-pregnant goats, which maintain low levels of prolactin and EPG, with a correlation of 0.83 between these characteristics (Rahman \& Collins, 1992). In dairy goats, the level of resistance/resilience is negatively correlated with the amount of milk produced (Hoste \& Chartier, 1993; Chartier et al., 1998).

\section{Leptin}

During pregnancy, the placenta is the main provider of leptin. The levels increase at this stage and decrease gradually as the lambing date and lactation approaches (Ingvartsen \& Boisclair, 2001; Mcfadin et al., 2002; Beasley et al., 2010). Ewes with high milk production and properly supplemented have a large amount of peri-renal fat, which in turn is related to a higher concentration of leptin in the blood and allows them to ensure fat tissue reserves and maintain good body condition (Rocha et al., 2011). On the 
other hand, leptin is an important regulator of the metabolic mechanisms of animals, and it has an important function in the immune system and in the activation of other hormones (Valderrábano et al., 2006). The function of leptin is linked to haematopoiesis and the induction of inflammation with activation of T lymphocytes, the production of Th1 cytokines and suppressing the production of Th2 cytokines (Ingvartsen \& Boisclair, 2001). Beasley et al. (2010) found in infected Merino sheep approaching lambing that their leptin levels decreased and EPG increased. Ewes not supplemented or with reduced intake during pregnancy tend to lose body condition and energy reserves and presenting reduced leptin levels, which are related to loss of immune capacity against infections (Rocha et al., 2011).

\section{Cortisol}

Cortisol is a glucocorticoid that is released with any stressful event (Caroprese et al., 2010), as occurs just before lambing. Circulating cortisol stimulates the production of anti-inflammatory cytokines and inhibits the production of pro-inflammatory cytokines such as interferon gamma (IFN-y), tumour necrosis factor (TNF-a) and interleukin-12 (IL-12); in addition, it inhibits the proliferation of T cells, modifies the action of Complement cells and alters the function of immunoglobulins (Aleri et al., 2016). All this leads to immunosuppression, increasing susceptibility to disease. At peripartum in ewes, the neutrophilia is commonly due to high cortisol levels at this time, which contributes to downregulation of surface adhesion molecules expression, in addition to an enhanced release of cells from the bone marrow (Ahmed et al., 2020). High cortisol levels in dairy cattle have been correlated with calcium and phosphorus deficiencies, causing hypocalcaemia problems in cows during the peripartum and provoking sensitivity to other infections (Kim et al., 2012).

\section{Pepsinogen}

Pepsinogen is a precursor to pepsin secreted by epithelial cells in the abomasum, the concentration of which generally increases at the time of expression of the immune response (Kidane et al., 2010), which coincides with the PPR from 4 weeks before lambing (Houdijk et al., 2000). An increase in pepsinogen concentrations is related to parasitism by Ostertagia spp. in abomasum (Simpson, 2000). As the parasite burden increases in the peripartum, the concentrations of pepsinogen and gastrin increase, the abomasum $\mathrm{pH}$ is altered, the abomasum permeability is increased and acid secretion is reduced (Houdijk et al., 2000; Davies et al., 2005; Angulo-Cubillán et al., 2007; Kidane et al., 2009), this being able to present diarrhoea (Miller \& Horohov, 2006). In this sense, pepsinogen is considered as a marker of the integrity of the abomasum mucosa and a pathological indicator (Dominik, 2005; Kidane et al., 2009; Cei et al., 2016).

\section{Albumin}

Protein levels in the diet are responsible for the concentrations of blood components during an infectious process (Louvandini et al., 2006). From two weeks before lambing and during lactation, ewes supplemented with high-protein diets maintain high concentrations of albumin and urea (Houdijk et al., 2000; Kidane et al., 2010), which coincides with a reduced excretion of eggs in the faeces; conversely, decreases in the level of albumin and urea favour an increase in EPG (Zárate Frutos et al., 2014). A low albumin concentration is also considered a pathological indicator of the presence of an infection (Dominik, 2005).

\section{Globulins}

Globulins are altered during de PPR in sheep infected with GIN. Regardless of the protein content in the diet, globulin levels increase from four weeks before lambing (Houdijk et al., 2000; Zárate Frutos et al., 2014). The increase at final pregnancy stage is related to the presence of infectious or parasitic diseases (Zárate Frutos et al., 2014). Immunoglobulins constitute a natural defence mechanism in sheep, associated with inflammatory processes and the formation of antibodies. At the same time, increases in serum globulin levels are related to the quality of colostrum (Obidike et al., 2009).

\section{Immunological mechanisms against parasitic infections}

Once the host is infected by the nematode larvae, the epithelial cells are stimulated to generate an immune response, together with complement fixation and mucus secretions constitute the innate response to resist the primary infection (Hendawy, 2018), characterised by the action of some cytokines (Klion \& Nutman, 2004). In addition, the small proteins and various cell types are stationary, such as interferons (IFNs) and virus-infected cells, or mobile, such as circulating leukocytes, monocytes, dendritic cells and lymphocytes. Leukocyte-derived cytokines are known as interleukins (ILs), and those originating from monocyte-macrophages are called monokines, both of which are produced as a protection mechanism for the host animal (Finkelman et al., 1997; Lippi et al., 2013; Karrow et al., 2014). Despite the fact that the immunological mechanisms are not very clear, the innate and acquired response capacity are those that have the greatest influence in the grade of infection (Muñoz-Guzmán et al., 2006). The acquired response dependent on previous exposure of the host to a foreign agent (González-Garduño et al., 2019) and characterised by specificity and antigen memory is the more important (Karrow et al., 2014). The immune response focuses on humoral and cellular responses (Gauly et al., 2002; Sayers \& Sweeney, 2005), as well as in inflammatory reactions (Angulo-Cubillán et al., 2007). These immunological bases are considered important because parasites, mainly those hosted in the intestinal lumen, are capable of producing immuno-modulatory substances that escape the host's immune response (Moreau \& Chauvin, 2010).

The innate response is the first line of defence, capable of rec- 
ognising molecular patterns associated with the pathogen in a shorter time, and occurs mainly through the Complement system (Fujita et al., 2004). A group of plasma proteins interact with bound antibodies and surface receptors that promote the elimination of pathogens (Castellano et al., 2004). By activating the classical and alternate pathways, high amounts of the enzyme C3 convertase are generated, depositing a large number of C3b molecules in the pathogen, attaching some molecules (opsonins) to its surface (Castellano et al., 2004; Fujita et al., 2004; Muñoz-Guzmán et al., 2006); through this opsonisation processes the elimination of pathogens occurs. In addition to this, the generated $\mathrm{C} 3 \mathrm{a}$ and C5a peptides facilitate the mobilisation of eosinophils and neutrophils, favouring the inflammatory reaction; Complement activation regulates the cytotoxicity of eosinophils against larvae in the early stages of infection (Muñoz-Guzmán et al., 2006).

\section{Cellular response}

In the peripartum period, the immunological differences between lactating and dry ewes are notable, so that the immunological relaxation in the peripartum include the low cellular and humoral response affected by hormonal and nutritional aspects modified by season changes (Beasley et al., 2012). The elements involved in the immune resistance or susceptibility of sheep consider the following concepts. T lymphocytes are responsible for directing the effector mechanisms once they are stimulated by antigens. When activated, CD4+ T cells differentiate into two groups: helper T cells or lymphocytes, Th1 and Th2 (Muñoz-Guzmán et al., 2006; Sykes, 2010). Th1 cells are responsible for increasing the expression of interleukins IL-2, IL-3, IL-13, IL-25, IFN- $\gamma$ and TNF-a (Finkelman et al., 1997; Miller \& Horohov, 2006; Hayward, 2013), as well as an increase in mRNA expression for IL-6 as an indicator of gene expression, while Th2 cells include IL-4, IL-5, IL-9, IL-10 and TGF- $\beta$, with effector mechanisms in the cellular immune response (Finkelman et al., 1997; Maza-Lopez et al., 2020). The expression of these components induces a local inflammatory reaction in which different types of cells, such as basophils, eosinophils, neutrophils and lymphocytes are involved, together with specific antibodies, the gastrointestinal mucosa and inflammatory mediators (Meeusen et al., 2005; Ingham et al., 2008; Karrow et al., 2014); in addition, dendritic cells (DCs) and natural killer cells (NK) appear (Angulo-Cubillán et al., 2007). These immunological mechanisms facilitate a reduction in the number, size and fertility of worms (Rowe et al., 2008). Intracellular parasites generally involve the Th1-type response, whereas GIN such as $H$. contortus involve the Th2-type response (Miller \& Horohov, 2006; Muñoz-Guzmán et al., 2006; Moreau \& Chauvin, 2010), although there are situations in which Th1 and Th2 responses are involved for certain parasites (Murphy et al., 2013). Results found by Bricarello et al. (2008) in Nelore cattle indicated that the immune response to Cooperia punctata was probably mediated by Th2 cytokines (IL-4 and IL-13) in resistant animals, and by Th1 cytokines (IL-2, IL-12p35, IFN-y and MCP-1) in the susceptible group.

\section{Eosinophilia}

As cellular components of immunity, eosinophils with a cytotoxic effect are one indicator of a parasitic infection. These cells have importance in the immune protection of infected animals (Hohenhaus et al., 1998; Davies et al., 2005). In the presence of GIN infections, effector immune responses characterised by the production of $\mathrm{lgE}$ and peripheral and tissue eosinophils associated with the production and activation of interleukins IL-4 and IL-5 are induced (Finkelman et al., 1997; Klion \& Nutman, 2004). Once in circulation, eosinophils release the content of their toxic granules or metabolites onto the nematode cuticle, increasing cellular cytotoxicity, with release of proteins and mediators of inflammation (Klion \& Nutman, 2004), favouring a lesion of the cuticle and the adherence of more eosinophils. In this way, regulation of the growth of GIN occurs together with the expulsion of eggs in the faeces of the host. Ewes in peripartum show a reduction in eosinophil count (Beasley et al., 2010; Pereira et al., 2020).

\section{Humoral immune response}

With GIN infection, the pro-inflammatory cytokines IL-4, IL-5, IL-9, $\mathrm{IL}-10$ and IL-13 are involved in different mechanisms of the humoral response. One of these is through the $\lg A, \lg G, \lg M$ and $\lg \mathrm{E}$ antibodies, which, being antigen receptors, prevent the invasion of pathogens through endocytosis of the antigen (O'Sullivan \& Donald, 1973; Beasley et al., 2010); another is due to delayed maturation, reduced fertility and induction of parasite death. They are also involved in intestinal contractility, allowing the expulsion of worms (Miller \& Horohov, 2006; Sayers et al., 2007; Houdijk, 2008; Hayward, 2013; Murphy et al., 2013; Wilkie et al., 2015). The surrounding IgA levels in the mucosa have been associated with reductions in the fertility and length of $H$. contortus, as well as a reduction in the parasite burden at the intestinal level (Amarante et al., 2005; Davies et al., 2005; Karrow et al., 2014; Hernández et al., 2016). Some studies have associated plasma $\lg$ A with FEC as an important immune response (Bowdridge et al., 2015; González-Garduño et al., 2018). High lgE levels are also involved in the expulsion of worms and in the regulation and activation of mast cells, eosinophils and basophils (Alba-Hurtado \& Muñoz-Guzmán, 2013; Murphy et al., 2013; Karrow et al., 2014). The expulsion of worms due to the effect of lgE occurs through the release of vasomotor amines: compounds that stimulate the contraction of smooth muscle and increase vascular permeability, allowing fluid to escape into the intestinal lumen, resulting in displacement and expulsion of most of the nematodes implanted in the intestinal mucosa of the animal. IgG concentrations are associated with a reduction in excreted eggs in faeces (Murphy et al., 2013).

\section{Genetic foundations of resistance}

Resistance against GIN is polygenic in nature (Sayers \& Sweeney, 2005; Zvinorova et al., 2016) and is quantitative; that is, it is influenced by a large set of genes or loci with small effects (Hayward, 
2013; Karrow et al., 2014). The identification of genes related to resistance to GIN involves procedures based on molecular genetics, through the use of molecular markers, and the application of different strategies such as mapping of quantitative traits locus (QTL) regions by linkage disequilibrium, identification of candidate genes, the use of maps of high-density single nucleotide polymorphism (SNP) and complete genome (genome-wide) association studies (Keane et al., 2006; Bishop \& Morris, 2007; Wilkie et al., 2015; Zvinorova et al., 2016), as well as microarray analysis, are very useful in determining post-infection gene expression. All these procedures offer advantages and opportunities to investigate resistance genetics and parasite-host interactions (Hayward, 2013).

\section{Genetic selection criteria}

The ability to express resistance between and within breeds is genetically regulated (Stear \& Murray, 1994), which is why selection can be made either directly through identifying the genes or alleles involved by means of molecular genetic techniques or indirectly through phenotypic indicators such as worm counts, FEC (Beh \& Maddox, 1996; Davies et al., 2005; Good et al., 2006), packed cell volume (PCV), antibody levels, specifically IgA and IgE (Karrow et al., 2014), eosinophil count, pepsinogen concentration (Beh \& Maddox, 1996) or other variables related to the immune response. One of the main variables by which the parasite burden is determined has been the EPG count, and this is one of the main phenotypic selection criteria. It must be evaluated by measurements over time, establishing the dynamics of the curve in the peripartum period and the correlation with other productive characteristics (Goldberg et al., 2012b).

Genetic selection is dependent on the heritability $\left(h^{2}\right)$, which in the case of FEC is considered moderately inheritable and highly repeatable (Bishop \& Morris, 2007; Saddiqi et al., 2010), similar to other productive characteristics. Values from 0.15 have been observed (Vanimisetti et al., 2004), but other authors indicate values of 0.25 to 0.30 (Sréter et al., 1994; Kahn et al., 1999) and even up to 0.63 (Miller \& Horohov, 2006; Alba-Hurtado \& Muñoz-Guzmán, 2013). Selective breeding of the maternal line for nematode resistance has potential epidemiological benefits by reducing pasture infectivity (Vineer et al., 2019).

\section{Identification of genes related to resistance}

The genetic basis of resistance is closely related to the immunological component, most of the loci involved with immunological processes are located in the Main Histocompatibility Complex (MHC), a highly polymorphic region that consists of a group of closely linked genes involved in the presentation of antigens in the host's immune system. Association of the FEC with the MHC I and MHC II regions adjacent to chromosome 20 of sheep has been found (Stear \& Murray, 1994; Karrow et al., 2014) with the amount of FEC (Keane et al., 2006; Karrow et al., 2014; Zvinorova et al., 2016). The DRB1 locus of MHC II has been associated with resistance to GIN, particularly with increases in $\lg A$ and $\lg \mathrm{E}$ levels (Dominik, 2005; Hassan et al., 2011; Hayward, 2013; Karrow et al., 2014). Also, with IFN-y gene located on chromosome 3 , a strong association between one allele of this gene has been detected with the reduction in FEC and an increase in the levels of specific antibodies (IgA) against Ostertagia circumcincta in lambs (Karrow et al., 2014). However, some authors have cited that expression of the IFN-y gene does not directly influence resistance to GIN (Dervishi et al., 2011; Alba-Hurtado \& Muñoz-Guzmán, 2013; Karrow et al., 2014). Likewise, with the lgE gene (Díaz et al., 2005; Pettit et al., 2005; Keane et al., 2006; Sayers et al., 2007; Karrow et al., 2014) a strong Th2 cell response has been detected during infections, with overexpression of IL-13, IL-5 and TNF-a (Alba-Hurtado \& Muñoz-Guzmán, 2013). The OMHC1-188 and OLADRB2-282 alleles of the MHC influence the differentiation between genotypes in the antigen-presenting mechanisms (Alba-Hurtado \& Muñoz-Guzmán, 2013). Of the TLR variants, the TLR4 gene is reported to be involved with the immune response to parasitic infections, as are other nearby genes, TNFSF8 and TNFSF15, which encode cytokines belonging to TNF- $a$ (Lin et al., 2016).

After evaluating the ALOX15, CD109, CD163, CPA3, EMR3, IL13 , KIT and MAP3K5 genes, it was found that ALOX15 and IL-13 play important roles in resistance to GIN (Wilkie et al., 2015) and were significantly increased in resistant animals and expression was negatively correlated with FEC. The expression of different genes at the intestinal level has been evaluated in two divergent lines by means of microarray analysis, with the highest expression in susceptible animals of HLA-A, MSH6, GPX2, IF135, UBD, SERPING1 and TFF3, the expression being generally associated with the stress caused by parasitic infection, such as in the case of GPX25; in contrast, resistant animals showed higher expression of the RAC2, ITGB2, DAP3 and TRADD genes associated with neutrophilia and post-infection cellular processes and of importance in innate immunity (Keane et al., 2006). As indicators of the genetic influence on resistance, the presence of QTL regions for EPG on chromosomes 1, 2, 3, 6, 14, 19 and 20 has been revealed for different nematodes, including $\mathrm{H}$. contortus, and on chromosome 1 for haematocrit (Bishop \& Morris, 2007). Other authors have reported different QTL regions in sheep for $H$. contortus, such is the case of chromosomes 1, 3, 6, 8, 14, 20 and 22 (Miller \& Horohov, 2006; Zvinorova et al., 2016).

\section{Factors influencing resistance and susceptibility}

The physiological, immunological and genetic effects that influence the resistance or susceptibility of ewes to GIN infections in the peripartum period are determined by the interaction of various factors:

Genotype or breed:

The resistance of some genotypes depends largely on conditions of environmental origin (Alba-Hurtado \& Muñoz-Guzmán, 2013) 


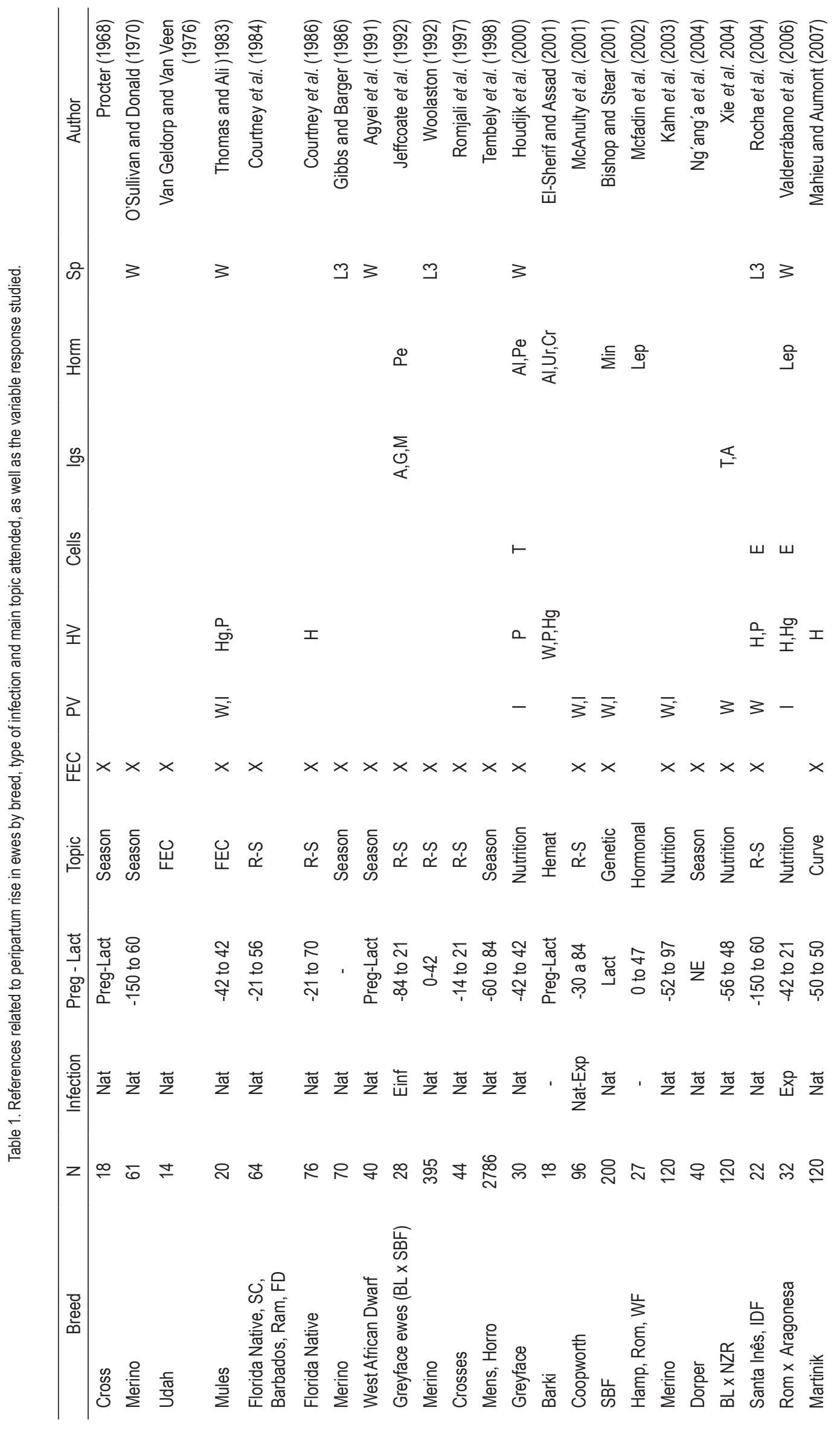




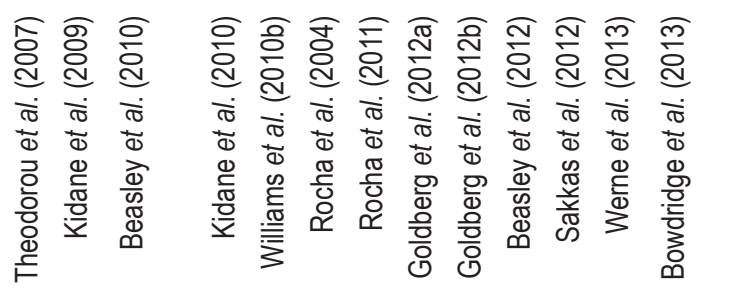

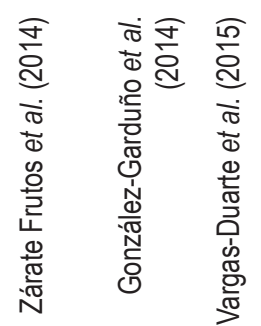

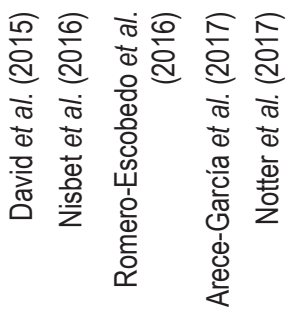

$3 \quad 9 \quad 939$

0
$\frac{1}{3}$

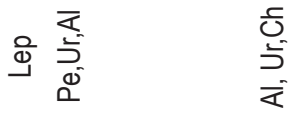

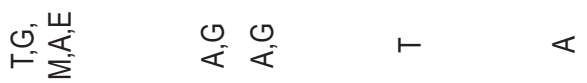

$\stackrel{9}{<}$

$\sum_{\substack{\infty \\ 2}}^{\infty}$

ш

з $\quad$ ш

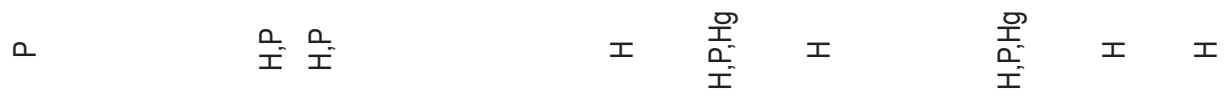

$3 \quad \overline{3} 33 \quad-\overline{3}-33$

$\times \times \times \times \times \times \times \times \times$

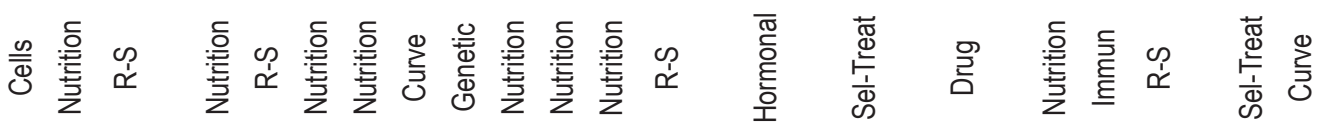

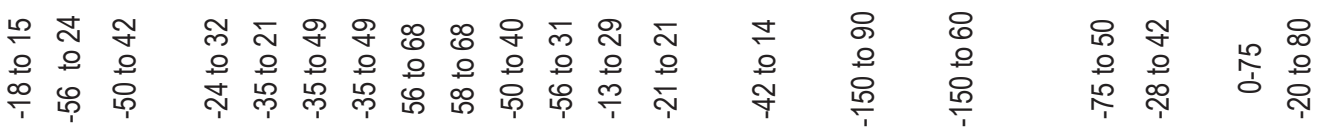

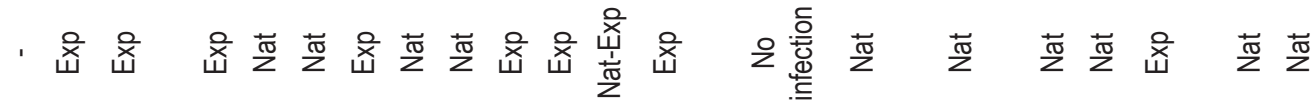

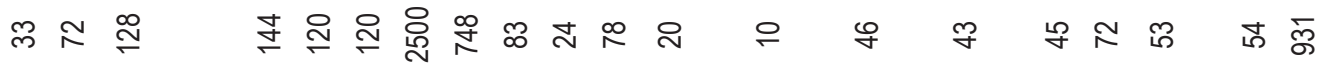

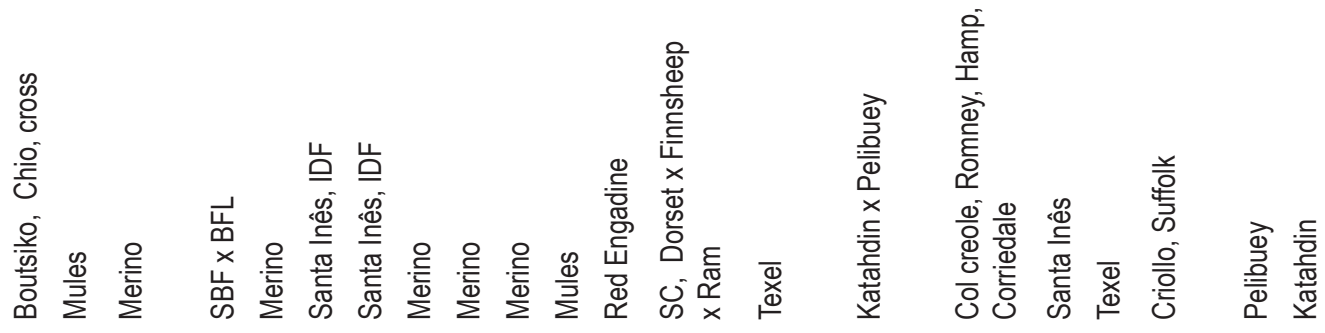




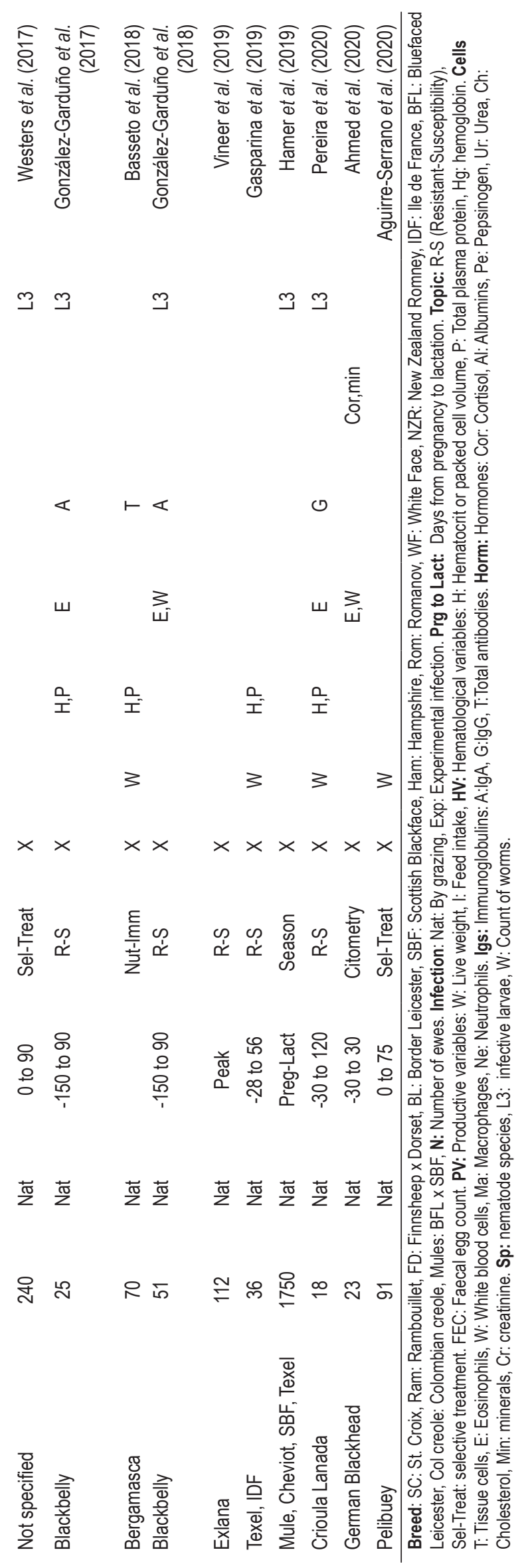


and flock management. Generally, native genotypes such as Red Maasai (Wanyangu et al., 1997), Santa Inés (Rocha et al., 2004; Albuquerque et al., 2019), Crioula Lanada (Bricarello et al., 2004), Barbados Blackbelly (Yazwinski et al., 1981; Zaragoza-Vera et al., 2019), Florida Native (Courtney et al., 1984, 1986; Díaz-Rivera et al., 2000), Castellana (Gómez-Muñoz et al., 1999), Pelibuey (Morteo-Gómez et al., 2004; Palomo-Couoh et al., 2017), and Mexican creole (Alba-Hurtado et al., 2010) are more resistant to $\mathrm{H}$. contortus. Native genotypes, which for many years have thrived in unfavourable environments with poor zootechnical management and without exposure to anthelmintic treatments have proven to be more resistant (Alba-Hurtado \& Muñoz-Guzmán, 2013). The use of genetically resistant animals can optimise the use of anthelmintics and delay the resistance capacity of nematodes against anthelmintics (Bricarello et al., 2004). In the same way, the selection of sheep resistant to GIN in the peripartum period would favour a decrease in the contamination of the pasture.

Nutrition:

In the peripartum period, ewes present an imbalance of nutrients that they require to maintain the final third of gestation and prepare the mammary gland for the next lactation (Barger, 1993; Jones et al., 2012). Since nutritional status is an important factor influencing the parasite-host relationship and the pathogenesis of infections (Valderrábano et al., 2006) and affecting the productive behaviour in ewes (Macarthur et al., 2014), adequate nutrition is a control measure, specifically in the critical stages of the final third of pregnancy and during lactation (Macarthur et al., 2014), that can improve the immune response of sheep (Houdijk et al., 2006; Kyriazakis \& Houdijk, 2006). Protein supplementation favours a greater presence of inflammatory cells in the abomasum mucosa, increasing the immune response and the animal's resistance and resilience to infection (Kyriazakis \& Houdijk, 2006; Rocha et al., 2011). Physiologically, it has been found that when supplementing with protein sources, hyperplasia occurs in the abomasum with a greater quantity of leukocytes and mast cells; after antigenic stimulation the mucosal mast cells release their content, making their function effective 21 days after the start of protein supplementation (Houdijk et al., 2006). Another important aspect of protein supplementation is that eosinophils are benefited, as they are a type of granulocyte related to the response to cells that contain protein-rich cytoplasmic granules (Hayward, 2013). However, supplementation can increase food costs (Davies et al., 2005). Results of a sheep-based meta-analysis suggested an important interaction between parasitism and dietary energy and protein consumption (Méndez-Ortíz et al., 2019). Infected animals require more energy to maintain a live weight gain similar to that of non-infected animals. An energy supply in addition to protein is required for the development of immune mechanisms (Toscan et al., 2017).

\section{Feed consumption:}

Infections in ruminants with GIN are characterised by a reduction in weight gain from 6 to $30 \%$ caused, in part, by a decrease in feed consumption (Kahn et al., 1999; Beasley et al., 2012). In parallel, nutritional requirements are increased up to six-fold compared to sheep outside this stage (Houdijk, 2008), which causes a decrease in gastrointestinal motility and a reduction in gastric acid secretion (Louvandini et al., 2006). This low consumption can cause significant protein losses, mainly in infections by blood-sucking nematodes such as $\mathrm{H}$. contortus. According to estimates, in sheep infected with Trichostrongylus colubriformis the losses are around 20 to $125 \mathrm{~g}$ of protein depending on infection level (Kahn et al., 1999; Angulo-Cubillán et al., 2007). All this favours the establishment and reproduction of the GIN with repercussions on the growth, productive efficiency and survival of the lambs.

\section{Age:}

Adult animals are able to respond better than younger ones (Goldberg et al., 2012a). Young animals' susceptibility is a consequence of their inability to develop a satisfactory immune response (Kahn et al., 1999; Emery et al., 2000; Getachew et al., 2007). They do not acquire effective immunity before 6 or 12 months of age (Williams et al., 2010a), but this improves as age progresses (Miller \& Horohov, 2006; Goldberg et al., 2012a). After puberty, females show differential resistance compared to males. Adult sheep tend to have a higher resistance capacity due to the simple fact that they have lived with parasites for a longer time (Courtney et al., 1984; Torres-Acosta \& Hoste, 2008) and with constant exposure to parasites and repeated infections, which is demonstrated by the high number of leukocytes (Miller \& Horohov, 2006), except when they are in the peripartum period when their immunity is reduced and when they cause greater contamination of the grazing area (Bishop \& Stear, 2001).

\section{Type of birth:}

There is some controversy regarding the effect of the type of birth because with the same feeding plan, lambs from single births have lower EPG values compared to those from a double birth; this is evident from the different related nutritional requirements with the number of products in gestation (Houdijk, 2008). Gruner et al. (1992) and Goldberg et al. (2012a) found that the type of birth had a significant effect, with mothers with multiple births showing higher EPG values than those with single delivery. Woolaston (1992) indicated that those ewes that lost their lambs during lactation had low EPG values. In other study, $>90 \%$ of the triplet-bearing ewes needed treatment, demonstrating the high treatment risk among ewes with large litter sizes (Aguirre-Serrano et al., 2020).

\section{Season:}

Under grazing management, the environmental conditions of the season influence the prevalence and relative dominance of some parasite species (Torres-Acosta \& Hoste, 2008), as well as the number of infective larvae (L3). The first studies related to the peripartum period reported that the increase in FEC was due 
to the high humidity in the grasslands being accentuated in the rainy season; in this season is common to find greater amounts of Trichostrongylus sp and Haemonchus sp, and this coincides with the time when ewes are lactating (Van Geldorp \& Van Veen, 1976). Later studies indicated that the parasitic eggs remain inhibited during the dry season and are reactivated in the rainy season, causing infection in the sheep when it coincides with the period of low immune response ( $\mathrm{Ng}^{\prime}$ ang'a et al., 2004).

\section{Hypobiotic state of the parasite:}

The hypobiotic state refers to an adaptation phenomenon of the parasite and the host interacting with the environment, particularly with temperature and humidity (Gibbs, 1982). Nematodes in their L4 larval stage enter a period of arrested development or hypobiosis (Miller \& Horohov, 2006; Angulo-Cubillán et al., 2007; Getachew et al., 2007), an adaptive mechanism to enable them to survive during extreme environmental conditions and is considered a defence mechanism. There is evidence that, in some regions with extreme temperature conditions, $H$. contortus worms can survive (Sargison et al., 2007) and increase their longevity, remaining in the host for up to 50 weeks (Getachew et al., 2007). When ewe's lactation coincides with the hypobiotic state of the parasites, it favours the development of the larval stages, providing a suitable environment for the development of the larval stages of the parasites. When ewe lactation starts, hypobiotic larvae resume development, as a consequence of which worm numbers increase and there is a rise in FEC (Taylor et al., 2016). It is quite probable that the impact of the phenomenon of hypobiosis in tropical and subtropical regions has a lesser effect that in template regions, as it is not well documented in those areas.

\section{Production system:}

Obviously, when sheep are under a grazing system, the degree of infection is higher than when they remain in stable. However, Silva et al. (2011) compared the peripartum behaviour of goats kept under a conventional system or in stables with goats under grazing conditions, and they didn't find significant differences between the two production systems. This similar behaviour was attributed to controlled management in both cases, whereas under extensive grazing and with little control the infection could be higher. However, under the same production system, management differences result in different parasitic behaviour (Vineer et al., 2019), which causes each farm to adopt different forms of control, giving priority to sustainable control in order to reduce anthelmintic resistance (Vande et al., 2018).

\section{Conclusions}

The genetic selection of resistant individuals is dependent on the heritability $\left(h^{2}\right)$, which is moderately inheritable and highly repeatable for FEC. The physiological, immunological and genetic effects that influence the resistance or susceptibility of sheep to GIN infec- tions in the peripartum period are in turn determined by the interaction of various factors, such as genotype or breed, nutrition, age, type of birth, time of year and production system, among others.

\section{Conflict of Interest}

Authors declare no conflict of interest.

\section{References}

Aboshady, H.M., Stear, M.J., Johansson, A., Jonas, E., Bambou, J.C. (2020): Immunoglobulins as biomarkers for gastrointestinal nematodes resistance in small ruminants: A systematic review. Sci Rep, 10(1): 1 - 14, DOI: 10.1038/s41598-020-64775-x

Aguirre-Serrano, A.M., Ojeda-Robertos, N., GonzÁlez-Garduño, R., Peralta-Torres, J.A., Luna-Palomera, C., Torres-Acosta, J.F.J. (2020): Influence of lambing and litter size at birth or weaning on the proportion of Pelibuey ewes treated with an anthelmintic in a targeted selective scheme in the humid tropics, Small Rumin. Res., 184: 106049. DOI: 10.1016/j.smallrumres.2020.106049

Agyel, A.D., Sapong, D., Probert, A.J. (1991): Periparturient rise in faecal nematode egg counts in West African Dwarf sheep in Southern Ghana in the absence of arrested strongyle larvae. Vet. Parasitol., 39(1-2): 79 - 88. DOI: 10.1016/0304-4017(91)90064-3 Ahmed, M.H., Wilkens, M.R., Möller, B., Ganter, M., Breves, G. (2020): Blood leukocyte composition and function in periparturient ewes kept on different dietary magnesium supply. BMC Vet. Res., 16: 1 - 14. DOI: 10.1186/s12917-020-02705-9

Alba-Hurtado, F., Muñoz-Guzmán, M.A. (2013): Immune responses associated with resistance to haemonchosis in sheep. BioMed Res. Int., 2013: 11. DOI: 10.1155/2013/162158

Alba-Hurtado, F., Romero-Escobedo, E., Muñoz-Guzmán, M.A., TorRes-Hernández, G., Becerril-Pérez, C.M. (2010): Comparison of parasitological and productive traits of Criollo lambs native to the central Mexican Plateau and Suffolk lambs experimentally infected with Haemonchus contortus. Vet. Parasitol., 172(3-4): 277 - 282. DOI: 10.1016/j.vetpar.2010.05.001

Albuquerque, A.C.A., Bassetto, C.C., Almeida, F.A., Hildersley, K.A., Mcneilly, T.N., Britton, C., Amarante, A.F.T. (2019): Differences in immune responses to Haemonchus contortus infection in the susceptible lle de France and the resistant Santa Ines sheep under different anthelmintic treatments regimens. Vet. Res., 50(1): 1 - 12. DOI: 10.1186/s13567-019-0722-3

Aleri, J.W., Hine, B.C., Pyman, M.F., Mansell, P.D., Wales, W.J., Mallard, B., Fisher, A.D. (2016): Periparturient immunosuppression and strategies to improve dairy cow health during the periparturient period. Res. Vet. Sci., 108: 8 - 17. DOI: 10.1016/j. rvsc.2016.07.007

Amarante, A.F.T., Bricarello, P.A., Huntley, J.F., Mazzolin, L.P., Gomes, J.C. (2005): Relationship of abomasal histology and parasite-specific immunoglobulin A with the resistance to Haemonchus contortus infection in three breeds of sheep. Vet. Parasitol., 128: 
99 - 107. DOI: 10.1016/j.vetpar.2004.11.021

Angulo-Cubillán, F.J., García-Coiradas, L., Cuquerella, M., De La Fuente, C., Alunda, J.M. (2007): Haemonchus contortus - sheep relationship: A review. Rev. Científ. FCV-LUZ., XVII(6): 577 - 587. Available in: $h$ ttp://www.redalyc.org/articulo.oa?id=95911668005

Arece-Garcia, J., López-Leyva, Y., González-Garduño, R., Torres-Hernández, G., Rojo-Rubio, R., Marie-Magdeleine, C. (2017): Effect of selective anthelmintic treatments on health and production parameters in Pelibuey ewes during lactation. Trop. Anim. Health Prod., 48(2): $283-287$

BARGER, I.A. (1993): Influence of sex and reproductive status on susceptibility of ruminants to nematode parasitism. Int. J. Parasitol., 23(4): 463 - 469. DOI: 10.1016/0020-7519(93)90034-V

Basripuzi, N.H., Salisı, M.S., Isa, N.M.M., Busin, V., Cairns, C., JenVEY, C., STEAR, M.J. (2018): Boer goats appear to lack a functional $\lg A$ and eosinophil response against natural nematode infection. Vet. Parasitol., 264: 18 - 25. DOI: 10.1016/j.vetpar.2018.10.014 Bassetto, C.C., Almeida, F.A., Newlands, G.F.J., Smith, W.D., Castilhos, A.M., Fernandes, S., Siqueira, E.R., Amarante, A.F.T. (2018): Trials with the Haemonchus vaccine, Barbervax $\AA$, in ewes and lambs in a tropical environment: Nutrient supplementation improves protection in periparturient ewes. Vet. Parasitol., 264: 52 - 57. DOI: 10.1016/j.vetpar.2018.11.006

BeAsley, A., KaHn, L., Windon, R. (2010): The periparturient relaxation of immunity in Merino ewes infected with Trichostrongylus colubriformis: Parasitological and immunological responses. Vet. Parasitol., 168: 60 - 70. DOI: 10.1016/j.vetpar.2009.08.028

BEASLEY, A.M., KaHn, L.P., Windon, R.G. (2012): The influence of reproductive physiology and nutrient supply on the periparturient relaxation of immunity to the gastrointestinal nematode Trichostrongylus colubriformis in Merino ewes. Vet. Parasitol., 188(3-4): 306 - 324. DOI: 10.1016/j.vetpar.2012.03.022

BeH, K.J., Maddox, J.F. (1996): Prospects for development of genetic markers for resistance to gastrointestinal parasite infection in sheep. Int. J. Parasitol., 26(8-9): 879 - 897. DOI: 10.1016/S00207519(96)80060-9

BISHOP, S.C., STEAR, M.J. (2001): Inheritance of faecal egg counts during early lactation in Scottish Blackface ewes facing mixed, natural nematode infections. Anim. Sci., 76(6): 389 - 395. DOI: 10.1017/S1357729800058355

BISHOP, S.C., MoRRIS, C.A. (2007): Genetics of disease resistance in sheep and goats. Small Rumin. Res., 70(1): 48 - 59. DOI: 10.1016/j.smallrumres.2007.01.006

Bowdridge, S., Mackinnon, K., Mccann, J.C., Zajac, A.M., NotTER, D.R. (2013): Hair-type sheep generate an accelerated and longer-lived humoral immune response to Haemonchus contortus infection. Vet. Parasitol., 196: 172 - 178. DOI: 10.1016/j.vetpar.2013.01.008

Bowdridge, S.A., ZAJAC, A.M., NotTer, D.R. (2015): St. Croix sheep produce a rapid and greater cellular immune response contributing to reduced establishment of Haemonchus contortus. Vet. Parasitol., 208(3-4): 204 - 210. DOI: 10.1016/j.vetpar.2015.01.019
Bricarello, P.A., Gennari, S.M., Oliveira-Sequeira, T.C.G., Vaz, C.M.S.L., De Gonçalves, I.G., Echevarria, F.A.M. (2004): Worm burden and immunological responses in Corriedale and Crioula Lanada sheep following natural infection with Haemonchus contortus. Small Rumin. Res., 51(1): 75 - 83. DOI: 10.1016/S09214488(03)00188-3

Bricarello, P.A., Zaros, L.G., Coutinho, L.L., Rocha, R.A., Silva, M.B., Kooyman, F.N.J., De Vries, E., Yatsuda, A.P., Amarante, A.F.T. (2008): Immunological responses and cytokine gene expression analysis to Cooperia punctata infections in resistant and susceptible Nelore cattle. Vet. Parasitol., 155(1-2): 95 - 103. DOl: 10.1016/j.vetpar.2008.03.016

Caroprese, M., Albenzio, M., Marzano, A., Schena, L., AnnicchiarICO, G., SEVI, A. (2010): Relationship between cortisol response to stress and behavior, immune profile, and production performance of dairy ewes. J. Dairy Sci., 93(6): 2395 - 2403. DOI: 10.3168/ jds.2009-2604

Castellano, G., Woltman, A.M., Paolo, F., Roos, A., Daha, M.R., Kooten, C. VAN (2004): Dendritic cells and complement: at the cross road of innate and adaptive immunity. Mol. Immunol., 41: 133 - 140. DOI: 10.1016/j.molimm.2004.03.018

Cei, W., Salah, N., Paut, C., Dumoulin, P.-J., Arquet, R., Félicité, Y., Alexandre, G., Archiméde, H., Bambou, J. (2016): Impact of the post-weaning nutritional history on the response to an experimental Haemonchus contortus infection in Creole goats and Black Belly sheep. Vet. Parasitol., 218: 87 - 92. DOI: 10.1016/j. vetpar.2016.01.015

Chartier, C., Hoste, H., Bouquet, W., Malpaux, B., Pors, I., Koch, C. (1998): Periparturient rise in fecal egg counts associated with prolactin concentration increase in French Alpine dairy goats. Parasitol. Res., 84(10): 806 - 810. DOI: 10.1007/s004360050492

Convey, E.M. (1974): Serum hormone concentration in ruminants during mammary growth, lactogenesis, and lactation: A review. J. Dairy Sci., 57(8): 905 - 917. DOI: 10.3168/jds.S00220302(74)84986-6

Courtney, C.H., Parker, C.F., Mcclure, K.E., Herd, R.P. (1984): A comparison of the periparturient rise in fecal egg counts of exotic and domestic ewes. Int. J. Parasitol., 14(4): 377 - 381. DOI: 10.1016/0020-7519(84)90092-4

Courtney, C.H., Parker, C.F., Mcclure, K.E., Herd, R.P. (1985): Resistance of exotic and domestic lambs to experimental infection with Haemonchus contortus. Int. J. Parasitol., 15(1): 101 - 109. DOI: 10.1016/0020-7519(85)90107-9

Courtney, C.H., Gessner, R., Sholz, S.R., Loggin, P.E. (1986): The periparturient rise in fecal egg counts in three strains of Florida Native ewes and its value in predicting resistance of lambs to Haemonchus contortus. Int. J. Parasitol., 16(3): 185 - 189. DOI: 10.1016/0020-7519(86)90042-1

David, C.M.G., Da Costa, R.L.D., Parren, G.A.E., Rua, M.A.S., NoRd, E.C.P., Окамото, F., Paz, C.C.P. (2015): Sugarcane and mulberry silage supplementation of sheep during the peripartum period. Trop. Anim. Health Prod., 47(4): 765 - 772. DOI: 10.1007/ 
s11250-015-0791-x

DaVIES, G., STEAR, M.J., BISHOP, S.C. (2005): Genetic relationships between indicator traits and nematode parasite infection levels in 6-month-old lambs. Anim. Sci., 80(2): 143 - 150. DOI: 10.1079/ ASC41290143

Dervishi, E., URiarte, J., Valderrábano, J., Calvo, J.H. (2011): Structural and functional characterisation of the ovine interferon gamma (IFNG) gene: its role in nematode resistance in Rasa Aragonesa ewes. Vet. Immunol. Immunopathol., 141(1-2): 100 - 108. DOI: 10.1016/j.vetimm.2011.02.013

Diaz-Rivera, P., Torres-Hernández, G., Osorio-Arce, M., PérezHernández, P., Becerril-Pérez, C., Herrera-Haro, J. (2000): Resistance to gastrointestinal parasites in Florida, Pelibuey and crossbred sheep in the mexican tropics. Agrociencia, 34(1): $13-20$

Diaz, S., Ripoli, M.V. Peral-García, P., Giovambattista, G. (2005): Marcadores genéticos para resistencia y susceptibilidad a enfermedades infecciosas en animales domésticos [Genetic markers for susceptibility and resistance to infectious diseases in farm animals]. Analecta Vet., 25(1): 40 - 52. Available in: http://sedici.unlp. edu.ar/handle/10915/11177 (In Spanish)

DomINIK, S. (2005): Quantitative trait loci for internal nematode resistance in sheep: a review. Gen. Sel. Evol., 37(Suppl 1): 83 - 96. DOI: 10.1051/gse:2004027

El-Sherif, M.M.A., Assad, F. (2001): Changes in some blood constituents of Barki ewes during pregnancy and lactation under semi arid conditions. Small Rumin. Res., 40(3): 269 - 277. DOI: 10.1016/S0921-4488(01)00174-2

Emery, D.L., Mcclure, S.J., Davey, R.J. (2000): Protection of Merino lambs against Haemonchus contortus by trickle infection of neonates, Parasitol. Int., 49(2): 165 - 170. DOI: 10.1016/S13835769(00)00038-6

Finkelman, F.D., Shea-Donohue, T., Goldhill, J., Sullivan, C.A., Morris, S.C., Kathleen, B., Gause, W.C., Urban, J.F. (1997): Cytokine regulation of host defense against parasitic gastrointestinal nematodes: Lessons from studies with rodent models. Annual Rev. Immunol., 15: 505 - 533. DOI: 10.1146/annurev.immunol.15.1.505 Fleming, M.W., ConRAD, S.D. (1989): Effects of exogenous progesterone and/or prolactin on Haemonchus contortus infections in ovariectomized ewes. Vet. Parasitol., 34(1-2): 57 - 62

Fthenakis, G.C., Mavrogianni, V.S., Gallidis, E., Papadopoulos, E. (2015): Interactions between parasitic infections and reproductive efficiency in sheep. Vet. Parasitol., 208: 56 - 66. DOI: 10.1016/j. vetpar.2014.12.017

FuJita, T., Endo, Y., Nonaka, M. (2004): Primitive complement system-recognition and activation. Mol. Immunol., 41(2-3): 103 - 111. DOI: 10.1016/j.molimm.2004.03.026

Gasparina, J.M., Fonseca, L., Lodd, M.M., De Souza M.A., Da RoCHA, R.A. (2019): Resistance of ewes to gastrointestinal nematode infections during the peripartum and dry periods and the performance of their lambs. Rev. Bras. Saude Prod. Animal., 20: 1 - 11. DOI: 10.1590/S1519-9940200282019
Gauly, M., Kraus, M., Vervelde, L., Van Leeuwen, M.A.W., Erhardt, G. (2002): Estimating genetic differences in natural resistance in Rhön and Merinoland sheep following experimental Haemonchus contortus infection. Vet. Parasitol., 106(1): 55 - 67. DOI: 10.1016/ S0304-4017(02)00028-6

Getachew, T., Dorchies, P., Jacquiet, P. (2007): Trends and challenges in the effective and sustainable control of Haemonchus contortus infection in sheep. Review. Parasite, 14(1): 3 - 14. DOI: 10.1051/parasite/2007141003

GIBBS, H.C. (1982): Mechanisms of survival of nematode parasites with emphasis on hypobiosis. Vet. Parasitol., 1(1): 25 - 48. DOI: 10.1016/0304-4017(82)90119-4

GIBBS, H.C., BARGER, I.A. (1986): Haemonchus contortus and other trichostrongylid infections in parturient, lactating and dry ewes. Vet. Parasitol., 22(1-2): 57 - 66. DOI: 10.1016/0304-4017(86)90007-5 Goldberg, V., Ciappesoni, G., Agullar, I. (2012a): Genetic parameters for nematode resistance in periparturient ewes and post-weaning lambs in Uruguayan Merino sheep. Livest. Sci., 147(1-3): 181 - 187. DOI: 10.1016/j.livsci.2012.05.003

Goldberg, V., Ciappesoni, G., Agullar, I. (2012b): Modelling the faecal worm egg count curve during the periparturient period in Uruguayan Merino sheep. Spanish J. Agric. Res., 10(4): 986 - 992. DOI: 10.5424/sjar/2012104-3256

Gómez-Muñoz, M.T., Cuquerella, M., Gómez-Iglesias, L.A., Méndez, S., Fernández-Pérez, F.J., De La Fuente, C., Alunda, J.M. (1999): Serum antibody response of Castellana sheep to Haemonchus contortus infection and challenge: relationship to abomasal worm burdens. Vet. Parasitol., 1(4): 281 - 293. DOI: 10.1016/S03044017(98)00260-X

Gonçalves, T.C., Alencar, M.M., Gigloti, R., Bilhassi, T.B., OlivelRA, H.N., Rabelo, M.D., Esteves, S.N., Oliveira, M.C.S. (2018): Resistance of sheep from different genetic groups to gastrointestinal nematodes in the state of São Paulo, Brazil. Small Rumin. Res., 166: 7 - 11. DOI: 10.1016/j.smallrumres.2018.07.003

González-Garduño, R., Torres-Acosta, J.F.J., Chay-Canul, A.J. (2014): Susceptibility of hair sheep ewes to nematode parasitism during pregnancy and lactation in a selective anthelmintic treatment scheme under tropical conditions. Res. Vet. Sci., 96(3): 487 - 492. DOI: 10.1016/j.rvsc.2014.03.001

González Garduño, R., López Arellano, M.E., Conde Felipe, M.M., Mendoza De Gives, P., Agullar Marcelino, L., Jasso Diaz, G. (2017): Immune and haematological parameters of Blackbelly ewes infected with gastrointestinal nematodes. Rev. Colomb. Cienc. Pec., 30: 219 - 230. DOI: 10.17533/udea.rccp.v30n3a05

González-Garduño, R., Mendoza-De Gives, P., López-Arellano, M.E., Aguilar-Marcelino, L., Torres-Hernández, G., OJeda-RoberTOS, N.F., TORRES-ACOSTA, J.F.J. (2018): Influence of the physiological stage of Blackbelly sheep on immunological behaviour against gastrointestinal nematodes". Exp. Parasitol., 193: 20 - 26. DOI: 10.1016/j.exppara.2018.08.003

González-Garduño, R., López-Arellano, M.E., Torres-Hernández, G., Oliva-Hernández, J., Hinojosa-Cuéllar, J.A. (2019): Assess- 
ment of acquired resistance in previously infected lambs with gastrointestinal nematodes in a tropical climate. Indian J. Anim. Res., 53(9): 1223 - 1228. DOI: 10.18805/ijar.B-928

Good, B., Hanrahan, J.P., Crowley, B.A., Mulcahy , G. (2006): Texel sheep are more resistant to natural nematode challenge than Suffolk sheep based on faecal egg count and nematode burden. Vet. Parasitol., 136(3-4): 317 - 327. DOI: 10.1016/j.vetpar.2005.12.001 Gruner, L., Bouix, J., Cabaret, J., Boulard, C., Cortet, J., Sauve, C., Molenat, G., Calamel, M. (1992): Effect of genetic type, lactation and management on helminth infection of ewes in an intensive grazing system on irrigated pasture. Int. J. Parasitol., 22(7): 919 - 925. DOI: 10.1016/0020-7519(92)90048-P

Gutiérrez-Amézquita, R.A., Morales-Montor, J., Muñoz-Guzmán, M.A., Nava-Castro, K.E., Ramirez-Álvarez, H., Cuenca-Verde, C., Moreno-Mendoza, N.A., Cuéllar-Ordaz, J.A., Alba-Hurtado, F. (2017): Progesterone inhibits the in vitro L3/L4 molting process in Haemonchus contortus. Vet. Parasitol., 248: 48 - 53. DOI: 10.1016/j.vetpar.2017.10.011

Hamer, K., Mcintyre, J., Morrison, A.A., Jennings, A., Kelly, R.F., Leeson, S., Bartley, D.J., Chaudhry, U., Busin, V., Sargison, N. (2019): The dynamics of ovine gastrointestinal nematode infections within ewe and lamb cohorts on three Scottish sheep farms. Prev. Vet. Med., 171: 104752. DOI: 10.1016/j.prevetmed.2019.104752 Hassan, M., Good, B., Hanrahan, J.P., Campion, D., Sayers, G., MulCAHY, G., SWEenEY, T. (2011): The dynamic influence of the DRB1*1101 allele on the resistance of sheep to experimental Teladorsagia circumcincta infection. Vet. Res. 42(1): 1 - 10. DOI: 10.1186/1297-9716-42-46

HAYWARD, A.D. (2013): Causes and consequences of intra- and inter-host heterogeneity in defence against nematodes. Parasite Immunol., 35(11): 362 - 373. DOI: 10.1111/pim.12054

HENDAWY, S.H.M. (2018): Immunity to gastrointestinal nematodes in ruminants: effector cell mechanisms and cytokines. J. Parasitic Diseases, 42(4): 471 - 482. DOI: 10.1007/s12639-018-1023-X

Hernández, J.N., Hernández, A., Stear, M., Conde-Felipe, M., Rodriguez, E., Piedrafita, D., González, J.F. (2016): Potential role for mucosal IgA in modulating Haemonchus contortus adult worm infection in sheep. Vet. Parasitol., 223: 153 - 158. DOI: 10.1016/j. vetpar.2016.04.022

Hoby, S., Schwarzenberger, F., Doherr, M.G., Robert, N., WalZER, C. (2006): Steroid hormone related male biased parasitism in chamois, Rupicapra rupicapra rupicapra. Vet. Parasitol., 138(3-4): 337 - 348. DOI: 10.1016/j.vetpar.2006.01.028

Hohenhaus, M.A., Josey, M.J., Dobson, C., Outteridge, P.M. (1998): The eosinophil leucocyte, a phenotypic marker of resistance to nematode parasites, is associated with calm behaviour in sheep. Immunol. Cell Biol., 76: 153 - 158. DOI: 10.1046/j.14401711.1998.00727.x

Hoste, H., Chartier, C. (1993): Comparison of the effects on milk production of concurrent infection with Haemonchus contortus and Trichostrongylus colubriformis in high-and low-producing dairy goats. Am. J. Vet. Res., 54(11): 1886 - 1893
HoudiJk, J.G.M., KyriazAkIs, I., Jackson, F., Huntley, J.F., Coop, R.L. (2000): Can an increased intake of metabolizable protein affect the periparturient relaxation in immunity against Teladorsagia circumcincta in sheep?. Vet. Parasitol., 91(1-2): 43 - 62. DOI: 10.1016/ S0304-4017(00)00255-7

HoudIJK, J.G.M., JaCKSON, F., CoOP, R.L., KYRIAZAKIS, I. (2006): Rapid improvement of immunity to Teladorsagia circumcincta is achieved through a reduction in the demand for protein in lactating ewes. Int. J. Parasitol., 36(2): 219 - 227. DOI: 10.1016/j.ijpara.2005.09.014 HoudIJK, J.G.M. (2008): Influence of periparturient nutritional demand on resistance to parasites in livestock. Parasite Immunol., 30(2): 113 - 121. DOI: 10.1111/j.1365-3024.2008.00992.x

Ingham, A., Reverter, A., Windon, R., Hunt, P., Menzies, M. (2008): Gastrointestinal nematode challenge induces some conserved gene expression changes in the gut mucosa of genetically resistant sheep. Int. J. Parasitol., 38(3-4): 431 - 442. DOI: 10.1016/j. ijpara.2007.07.012

INGVARTSEN, K.L., BoISCLAIR, Y.R. (2001): Leptin and the regulation of food intake, energy homeostasis and immunity with special focus on periparturient ruminants. Domestic Anim. Endocrinol., 21(4): 215 - 250. DOI: 10.1016/S0739-7240(02)00119-4

JeffCoate, I.A., Wedrychowicz, H., Fishick, G., Dunlop, E.M., DunCAN, J.L., Holmes, P.H. (1992): Pathophysiology of the periparturient egg rise in sheep: a possible role for IgA. Res. Vet. Sci., 53(2): 212 - 218. DOI: 10.1016/0034-5288(92)90112-F

Jones, L., SAKKas, P., HoudiJK, J., Knox, D., KyrIAZAKIS, I. (2012): Amelioration of the periparturient relaxation of immunity to parasites through a reduction in mammalian reproductive effort. Int. J. Parasitol., 42: 127 - 134. DOI: 10.1016/j.jpara.2012.09.010 Jonsson, N.N., Fortes, M.R.S., Piper, E.K., Vankan, D.M., CisnerOS, J.P.J. WITTEK, T. (2013): Comparison of metabolic, hematologi$\mathrm{cal}$, and peripheral blood leukocyte cytokine profiles of dairy cows and heifers during the periparturient period. J. Dairy Sci., 96(4): 2283 - 2292. DOI: 10.3168/jds.2012-6173

KaHn, L., KnoX, M., GraY, G. (1999): Enhancing immunity to nematode parasites in pregnant and lactating sheep through nutrition and genetic selection. Recent Adv. Anim. Nut. Australia, 12: $15-22$

Kann, G., Denamur, R. (1973): Possible role of prolactin during the oestrus cycle and gestation in the ewe. J. Reprod. Fertility., 39: $473-483$

Kahn, L.P., Knox, M.R., Gray, G.D., Lea, J.M., Walkden-Brown, S.W. (2003): Enhancing immunity to nematode parasites in single-bearing Merino ewes through nutrition and genetic selection. Vet. Parasitol., 112(3): 211 - 225. DOI: 10.1016/S03044017(02)00438-7

Karrow, N.A., Goliboski, K., Stonos, N., Schenkel, F., Peregrine, A. (2014): Review: Genetics of helminth resistance in sheep. Canadian J. Anim. Sci., 94(1): 1 - 9. DOI: 10.4141/CJAS2013-036 Keane, O.M., Zadissa, A., Wilson, T., Hyndman, D.L., Greer, G.J., Baird, D.B., Mcculloch, A.F., Crawford, A.M., Mcewan, J.C. (2006): Gene expression profiling of Naïve sheep genetically resistant and 
susceptible to gastrointestinal nematodes. BMC Genomics, 7: 1 - 12. DOI: 10.1186/1471-2164-7-42

Kidane, A., Houdisk, J., Athanasiadou, S., Tolkamp, B., Kyriazakis, I. (2010): Nutritional sensitivity of periparturient resistance to nematode parasites in two breeds of sheep with different nutrient demands. British J. Nutr., 104(10): 1477 - 1486. DOI: 10.1017/ S0007114510002503

Kidane, A., Houdisk, J.G., Tolkamp, B.J., Athanasiadou, S., KyrlAZAKIS, I. (2009): Consequences of infection pressure and protein nutrition on periparturient resistance to Teladorsagia circumcincta and performance in ewes. Vet. Parasitol., 165(1-2): 78 - 87. DOl: 10.1016/j.vetpar.2009.06.039

Kim, D., Yamagishi, N., Devkota, B., Furuhama, K. (2012): Effects of cortisol secreted via a 12-h infusion of adrenocorticotropic hormone on mineral homeostasis and bone metabolism in ovariectomized cows. Domestic Anim. Endocrinol., 43(3): 264 - 269. DOl: 10.1016/j.domaniend.2012.04.002

KLION, A.D., Nutman, T.B. (2004): Current perspectives The role of eosinophils in host defense against helminth parasites. J. Allergy Clin. Immunol., 113(1): 30 - 37. DOI: 10.1016/j.jaci.2003.10.050

KyRIAZAKIS, I., HoudIJK, J. (2006): Immunonutrition: nutritional control of parasites. Small Rumin. Res., 62(1-2): 79 - 82. DOl: 10.1016/j.smallrumres.2005.07.036

Lalramhluna, M., Bordolol, G., Pandit, S., Baidya, S., Joardar, S.N., PATRA, A.K., JAs, R. (2020): Parasitological and immunological response to Haemonchus contortus infection: Comparison between resistant Garole and susceptible Sahabadi sheep. Vet. Parasitol., Regional Studies and Reports, 22: 100477. DOI: 10.1016/j. vprsr.2020.100477

Lin, Y.S., Zhou, H., Forrest, R.H.J., Frampton, C.M., Burrows, L.E.R., HICKFORD, J.G.H. (2016): Association between variation in faecal egg count for a natural mixed field-challenge of nematode parasites and TLR4 variation. Vet. Parasitol., 218: 5 - 9. DOI: 10.1016/j.vetpar.2016.01.004

LipPI, E., Do Rêgo L, M.L., Hamad M, A.H., Aires, A.R., Coop, R.L., JACKSON, F., SUtTLE, N.F. (2013): Effects of parasitism on cellular immune response in sheep experimentally infected with Haemonchus contortus. Vet. Parasitol., 196(1-2): 230 - 234. DOI: 10.1016/j.vetpar.2013.02.014

Louvandini, H., Veloso, C.F.M., Paludo, G.R., Dell'porto, A., GenNARI, S.M., Mcmanus, C.M. (2006): Influence of protein supplementation on the resistance and resilience on young hair sheep naturally infected with gastrointestinal nematodes during rainy and dry seasons. Vet. Parasitol., 137(1-2): 103 - 111. DOI: 10.1016/j. vetpar.2006.01.004

Macarthur, F.A., Kahn, L.P., Windon, R.G. (2014): The influence of dietary manipulations and gastrointestinal nematodes on twin-bearing merino ewes and determinants of lamb survival. Livest. Sci., 167(1): 342 - 352. DOI: 10.1016/j.livsci.2014.05.019 Mahieu, M., Aumont, G. (2007): Periparturient rise in Martinik Hair Sheep and perspectives for gastrointestinal nematode control. Trop. Anim. Health Prod., 39(6): 387 - 390. DOI: 10.1007/s11250-
007-9029-X

Maza-Lopez, J., Pacheco-Armenta, M.J., Reyes-Guerrero, D.E., Olmedo-Juárez, A., GonzÁlez-Garduño, R., OlazarÁn-Jenkins, S., López-Arellano, M.E. (2020): Immune response related to Pelibuey sheep naturally infected with gastrointestinal nematodes in a tropical region of Mexico. Vet. Parasitol., Regional Studies and Reports. 21: 100422. DOI: 10.1016/j.vprsr.2020.100422

Mcanulty, R.W., Familton, A.S., Sedcole, R.D., Sykes, A.R. (2001): Changes in the resistance of the ewe to infection with Teladorsagia circumcincta during late pregnancy and lactation. Anim. Sci., 72(1): 159 - 168. DOI: 10.1017/S135772980005565X

Mcfadin, E.L., Morrison, C.D., Buff, P.R., Whitley, N.C., Keisler, D.H. (2002): Leptin concentrations in periparturient ewes and their subsequent offspring, J. Anim. Sci., 80: 738 - 743. DOI: 10.2527/2002.803738x

Meeusen, E.N.T., Balic, A., Bowles, V. (2005): Cells, cytokines and other molecules associated with rejection of gastrointestinal nematode parasites. Vet. Immunol. Immunopathol., 108: 121 - 125. DOI: 10.1016/j.vetimm.2005.07.002

Méndez-Ortíz, F.A., Sandoval-Castro, C.A., Vargas-Magaña, J.J., Sarmiento-Franco, L., Torres-Acosta, J.F.J., Ventura-Cordero, J. (2019): Impact of gastrointestinal parasitism on dry matter intake and live weight gain of lambs: A meta-analysis to estimate the metabolic cost of gastrointestinal nematodes. Vet. Parasitol., 265: 1 - 6. DOI: 10.1016/j.vetpar.2018.11.008

Miller, J.E., Horohov, D.W. (2006): Immunological aspects of nematode parasite control in sheep. J. Anim. Sci., 84(Suppl): 124 - 132. DOI: $10.2527 / 2006.8413$ supplE124x

Miura, H., Yamazaki, T., Kikuchi, M., Sakaguchi, M. (2019): Plasma steroid hormone concentrations and their relationships in Suffolk ewes during gestation and parturition. Anim. Sci. J., 90(11): 1426 - 1431. DOI: 10.1111/asj.13286

Moreau, E., Chauvin, A. (2010): Immunity against helminths: Interactions with the host and the intercurrent infections. J. Biomedicine Biotechnol., 2010(428593): 1 - 9. DOI: 10.1155/2010/428593 Morteo-Gómez, R., GonzÁlez-Garduño, R., Torres-Hernández, G., Nuncio-Ochoa, G., Becerril-Pérez, C.M., Gallegos-Sánchez, J., Aranda-lBañEz, E. (2004): Effect of the phenotypic variation in the resistance of Pelibuey lambs to the infestation with gastrointestinal nematodes. Agrociencia, 38(4): 395 - 404

Mugambi, J., Audho, J., Baker, R. (2005): Evaluation of the phenotypic performance of a Red Maasai and Dorper double backcross resource population: natural pasture challenge with gastrointestinal nematode parasites. Small Rumin. Res., 56: 239 - 251. DOI: 10.1016/j.smallrumres.2004.06.003

Muñoz-Guzmán, M.A., Cuéllar-Ordaz, J.A., Valdivia-Anda, A.G., BuendíA-Jiménez, J.A., Alba-Hurtado, F. (2006): Correlation of parasitological and immunological parameters in sheep with high and low resistance to haemonchosis, Canadian J. Anim. Sci., 86: 363 - 371. DOI: 10.4141/A06-010

Murphy, L., Pathak, A.K., Cattadori, I.M. (2013): A co-infection with two gastrointestinal nematodes alters host immune responses and 
only partially parasite dynamics. Parasite Immunol., 35: 421 - 432. DOI: 10.1111/pim.12045

Ng'Ang'A, C., Munyua, W., Maingl, N., Kanyari, P. (2004): Ocurrence of peri-parturient rise in trichostrongylid nematode egg output in Dorper ewes in a semi-arid area of Kajiado District of Kenya. Acta Trop., 92: 213 - 218. DOI: 10.1016/j.actatropica.2004.05.016 Nisbet, A.J., Mcneilly, T.N., Greer, A.W., Bartley, Y., Oliver, E.M., Smith, S., Palarea-Albaladejo, J., Matthews, J.B. (2016): Protection of ewes against Teladorsagia circumcincta infection in the periparturient period by vaccination with recombinant antigens. Vet. Parasitol., 228: 130 - 136. DOI: 10.1016/j.vetpar.2016.09.002 Notter, D.R., Burke, J.M., Miller, J.E., Morgan, J.L.M. (2017): Factors affecting fecal egg counts in periparturient Katahdin ewes and their lambs. J. Anim. Sci., 95(1): 103 - 112. DOI: 10.2527I jas2016.0955

O'sullivan, B.M., Donald, A.D. (1970): A field study of nematode parasite populations in the lactating ewe. Parasitology, 61(2): 301 - 315. DOI: 10.1017/S0031182000041135

O'sullivan, B.M., DonaLd, A.D. (1973): Responses to infection with Haemonchus contortus and Trichostrongylus colubriformis in ewes of different reproductive status, Int. J. Parasitol., 3: 521 -530. DOI: 10.1016/0020-7519(73)90049-0

OBIDIKE, I.R., AKA, L.O., OKAFOR, C.I. (2009): Time-dependant peri-partum haematological, biochemical and rectal temperature changes in West African dwarf ewes. Small Rumin. Res., 82(1): 53 - 57. DOI: 10.1016/j.smallrumres.2009.01.012

Palomo-Couoh, J.G., Aguilar-Caballero, A.J., Torres-Acosta, J.F.J., GonzÁlez-Garduño, R. (2017): Comparing the phenotypic susceptibility of Pelibuey and Katahdin female lambs against natural gastrointestinal nematode infections under hot humid tropical conditions. Parasitol. Res., 116(6). DOI: 10.1007/s00436-0175437-7

Pereira, F.C., Longo, C., Castilho, C., Leme, D.P., Seugling, J., Bassetto, C.C., Amarante, A.F.T., Bricarello, P.A. (2020): Peripartum phenomenon in Crioula Lanada sheep susceptible and resistant to gastrointestinal nematodes. Frontiers Vet. Sci., 7: 1 - 8. DOI: 10.3389/fvets.2020.00598

Pettit, J.J., Jackson, F., Rocchi, M., Huntley, J.F. (2005): The relationship between responsiveness against gastrointestinal nematodes in lambs and the numbers of circulating lgE-bearing cells. Vet. Parasitol., 134(1-2): 131 - 139. DOI: 10.1016/j.vetpar.2005.06.014

PhillipPS, H.R., YIP, S.H., GratTAn, D.R. (2020): Patterns of prolactin secretion. Mol. Cel. Endocrinol., 502(110679): 1 - 15. DOI: 10.1016/j.mce.2019.110679

Procter, B.G., GibBS, H.C. (1968): Studies on the spring rise phenomenon in ovine helminthiasis. I. Spring rise in stabled sheep. Can. J. Comp. Med. Vet. Sci., 32(1): $359-365$

Rahman, W.A., Collins, G.H. (1992): An association of faecal egg counts and prolactin concentrations in sera of periparturient Angora goats. Vet. Parasitol., 43(1-2): 85 - 91. DOI: 10.1016/03044017(92)90051-A
Ranilla, M., Sulon, J., Carro, M., Mantecón, A., Beckers, J. (1994): Plasmatic profiles of pregnancy-associatted glycoprotein and progesterone levels during gestation in Churra and Merino sheep. Theriogenololy, 42(3): $537-545$

Rocha, R.A., Amarante, A.F.T., Bricarello, P.A. (2004): Comparison of the susceptibility of Santa Inês and lle de France ewes to nematode parasitism around parturition and during lactation. Small Rumin. Res., 55(1-3): 65 - 75. DOI: 10.1016/j.smallrumres.2003.12.004

Rocha, R.A., Bricarello, P.A., Silva, M.B., HoudiJk, J.G.M., Almeida, F.A., Cardia, D.F.F., Amarante, A.F.T.D. (2011): Influence of protein supplementation during late pregnancy and lactation on the resistance of Santa Ines and lle de France ewes to Haemonchus contortus. Vet. Parasitol., 181(2-4): 229 - 238. DOI: 10.1016/j. vetpar.2011.03.055

Romero-Escobedo, E., Torres-Hernández, G., Becerril-Pérez, C.M., Alarcón-Zúñiga, B., Apodaca-Sarabia, C.A., Diaz-Rivera, P. (2018): A comparison of criollo and Suffolk ewes for resistance to Haemonchus contortus during the periparturient period. J. Appl. Anim. Res., 46(1): 17 -23. DOI: 10.1080/09712119.2016.1252378 Romual, E., Batubara, A., Pandey, V.S., Gatenby, R.M. (2000): Peri-parturient rise in faecal strongyle egg counts of different genotypes of sheep in North Sumatra, Indonesia. Vet. Parasitol., 68(1997): 191 - 196. DOI: 10.1016/s0304-4017(96)01008-4

Rowe, A., Mcmaster, K., Emery, D., Sangster, N. (2008): Haemonchus contortus infection in sheep: Parasite fecundity correlates with worm size and host lymphocyte counts. Vet. Parasitol., 153(34): 285 - 293. DOI: 10.1016/j.vetpar.2008.01.040

SAdDIQI, H.A., IQbal, Z., Khan, M.N., Muhammad, G. (2010): Comparative resistance of sheep breeds to Haemonchus contortus in a natural pasture infection. Int. J. Agric. Biol., 12(5): $739-743$.

Sakkas, P., HoudiJk, J.G.M., Athanasiadou, S., Kyriazakis, I. (2012): Sensitivity of periparturient breakdown of immunity to parasites to dietary protein source. J. Anim. Sci., 90(11): 3954 - 3962. DOI: 10.2527/jas.2011-4829

Sargison, N.D., Wilson, D.J., Bartley, D.J., Penny, C.D., Jackson, F. (2007): Haemonchosis and teladorsagiosis in a Scottish sheep flock putatively associated with the overwintering of hypobiotic fourth stage larvae. Vet. Parasitol., 147(3-4): 326 - 331. DOl: 10.1016/j.vetpar.2007.04.011

Sayers, G., Good, B., Hanrahan, J.P., O'donovan, J., Mulcahy, G., SWEeney, T. (2007): Breed differences in mucosal and systemic antibody response to nematode infection in sheep: an important role for IgE? Parasitology, 135: 71 - 80. DOI: 10.1017/ S0031182007003630

Sayers, G., Sweeney, T. (2005): Gastrointestinal nematode infection in sheep-a review of the alternatives to anthelmintics in parasite control. Anim. Health Res. Rev., 6(2): 159 - 171. DOI: 10.1079/AHR2005108

Silva, J.B., Fagundes, G.M., FonsecA, A.H. (2011): Dynamics of gastrointestinal parasitoses in goats kept in organic and conventional production systems in Brazil. Small Rumin. Res., 98(1-3): 
35 - 38. DOI: 10.1016/j.smallrumres.2011.03.014

SIMPSON, H.V. (2000): Pathophysiology of abomasal parasitism: is the host or parasite responsible? The Vet. J., 160(3): 177 - 191. DOI: $10.1053 /$ tvjl.2000.0491

SRÉTER, T., KASSAI, T., TAKÁCS, E. (1994): The heritability and specificity of responsiveness to infection with Haemonchus contortus in sheep. Int. J. Parasitol., 24(6): 871 - 876. DOI: 10.1016/00207519(94)90013-2

Stear, M., MurRay, M. (1994): Genetic resistance to parasitic disease: Particularly of resistance in ruminants to gastrointestinal nematodes. Vet. Parasitol., 54(1-3): 161 - 176. DOI: 10.1016/03044017(94)90089-2

SYKES, A.R. (2010): Host immune responses to nematodes: benefit or cost? Implications for future development of sustainable methods of control. Rev. Bras. Zoot., 39(S): 376 - 382. DOI: 10.1590/S1516-35982010001300041

TAYLOR, M., SARGISON, N., HowE, M. (2016): Dosing ewes at lambing time. Vet. Record., 178(15): 377 - 378. DOI: 10.1136/vr.i1978

Tembely, S., Lahlou-Kassi, A., Rege, J.E.O., Mukasa-Mugerwa, E., ANINDO, D., SovanI, S., BAKER, R.L. (1998): Breed and season effects on the peri-parturient rise in nematode egg output in indigenous ewes in a cool tropical environment. Vet. Parasitol., 77(2-3): 123 - 132. DOI: 10.1016/S0304-4017(97)00219-7

Theodorou, G., Fragou, S., Chronopoulou, R., Kominakis, A., RogDAKIS, E., PoLITIS, I. (2007): Study of immune parameters in three greek dairy sheep breeds during the periparturient period. J. Dairy Sci., 90(12): 5567 - 5571. DOI: 10.3168/jds.2007-0247

Thomas, R., Alı, D. (1983): The effect of Haemonchus contortus infection on the pregnant and lactating ewes. Int. J. Parasitol., 13(4): $393-398$

Torres-Acosta, F., Rodriguez-Vivas, R. (1995): Efecto del parto sobre la eliminación de huevecillos de nemátodos y ooquistes de Eimeria en cabras criollas [The effect of parturition on nematode egg and oocyst output of Eimeria in criollo goats]. Rev. Biomedica, 6(4): 208 - 215 (In Spanish)

ToRres-Acosta, J., Hoste, H. (2008): Alternative or improved methods to limit gastro-intestinal parasitism in grazing sheep and goats. Small Rumin. Res., 77: 159 - 173. DOI: 10.1016/j.smallrumres.2008.03.009

Toscan, G., Cauduro, G., Tadinello, J.F., Weber, A., Heinloft, H., MedeIROS, M., SangIONI, L.A., SilveIRA, F. (2017): Immune response of sheep naturally infected with Haemonchus spp. on pastures with two different nutritional conditions. Semina: Ciênc. Agrárias, 38(2): 809 - 819. DOI: 10.5433/1679-0359.2017v38n2p809

Trenti, A., Tedesco, S., Boscaro, C., Trevisi, L., Bolego, C., Cignarella, A. (2018): Estrogen, angiogenesis, immunity and cell metabolism: Solving the puzzle. Int. J. Mol. Sci., 19(3). DOI: 10.3390/ijms 19030859

ValderRábano, J., Gómez-Rincón, C., URIaRTe, J. (2006): Effect of nutritional status and fat reserves on the periparturient immune response to Haemonchus contortus infection in sheep. Vet. Parasitol., 14: 122 - 131. DOI: 10.1016/j.vetpar.2006.04.029
Van Geldorp, P.J.A., Van Veen, T.S. (1976): Periparturient rise in faecal helminth egg counts of Udah sheep in the Zaria area of Nigeria. Vet. Parasitol., 1(3): 265 - 269. DOI: 10.1016/03044017(76)90099-6

Vande, F., Charler, J., Claerebout, E. (2018): Farmer behavior and gastrointestinal nematodes in ruminant livestock-uptake of sustainable control approaches. Frontiers Vet. Sci., 5. DOI: 10.3389/fvets.2018.00255

Vanimisetti, H.B., AndRew, S.L., Zajac, A.M., Notter, D.R. (2004): Inheritance of fecal egg count and packed cell volume and their relationship with production traits in sheep infected with Haemonchus contortus. J. Anim. Sci., 82(6): 1602 - 1611. DOI: 10.2527/2004.8261602x

Vargas-Duarte, J.J., Lozano-Márquez, H., Grajales-Lombana, H.A., Manrique-Perdomo, C., Martinez-Bello, D.A., Saegerman, C., Raes, M., KIRSCHVINK, N. (2015): Effect of moxidectin treatment at peripartum on gastrointestinal parasite infections in ewes raised under tropical Andes high altitude conditions. Vet. Med. Int., 2015: 1 - 8 . DOI: 10.1155/2015/932080

Vázquez-Hernández, M., González-Garduño, R., Torres-Hernández, G., Mendoza De Gives, P., Ruiz-Rodríguez, J. (2006): Comparison of two grazing systems in the infestation with gastrointestinal nematodes of hair sheep. Vet. Mex., 37(1): $18-27$

Vineer, H.R., Baber, P., White, T., Morgan, E.R. (2019): Reduced egg shedding in nematode-resistant ewes and projected epidemiological benefits under climate change. Int. J. Parasitol., 49(12): 901 - 910. DOI: 10.1016/j.jpara.2019.06.008

Wanyangu, S.W., Mugambi, J.M., Bain, R.K., Duncan, J.L., MurRay, M., SteAR, M.J. (1997): Response to artificial and subsequent natural infection with Haemonchus contortus in Red Maasai and Dorper ewes. Vet. Parasitol., 69(3-4): 275 - 282. DOI: 10.1016/ S0304-4017(96)01129-6

Werne, S., Perler, E., Maurer, V., Probst, J.K., Hoste, H., Drewek, A., HECKENDORN, F. (2013): Effect of sainfoin (Onobrychis viciifolia) and faba bean (Vicia faba) on the periparturient rise in ewes infected with gastrointestinal nematodes. Small Rumin. Res., 113(2-3): 454 - 460. DOI: 10.1016/j.smallrumres.2013.03.022

Westers, T., Jones-Bitton, A., Menzies, P., Vanleeuwen, J., PolJAK, Z., PEREGRINE, A.S. (2017): Comparison of targeted selective and whole flock treatment of periparturient ewes for controlling Haemonchus sp. on sheep farms in Ontario, Canada. Small Rumin. Res., 150: 102 - 110. DOI: 10.1016/j.smallrumres.2017.03.013 WILKIE, H., Xu, S., Gossner, A., HopkINS, J. (2015): Variable exon usage of differentially-expressed genes associated with resistance of sheep to Teladorsagia circumcincta. Vet. Parasitol., 212(3-4): 206 - 213. DOI: 10.1016/j.vetpar.2015.08.023

Willams, A.R., GreefF, J.C., Vercoe, P.E., Dobson, R.J., Karlsson, L.J.E. (2010a): Merino ewes bred for parasite resistance reduce larval contamination onto pasture during the peri-parturient period. Animal, 4(1): 122 - 127. DOI: 10.1017/S1751731109990802 Willams, A.R., Palmer, D.G., Williams, I.H., Vercoe, P.E., Emery, D.L., Karlsson, L.J.E. (2010b): Relationships between immune 
indicators of parasitic gastroenteritis, nematode burdens and faecal dry matter in sheep. Anim. Prod. Sci., 50: 219 - 227. DOI: 10.1071/AN09144

WOOLASTON, R.R. (1992): Selection of Merino sheep for increased and decreased resistance to Haemonchus contortus: peri-parturient effects on faecal egg counts. Int. J. Parasitol: Drugs and Drug Resist., 22(7): 947 - 953. DOI: 10.1016/0020-7519(92)90052-M

Xie, H.L., Stankiewicz, M., Huntley, J.F., Sedcole, J.R., Mcanulty, R.W., GREEN, R.S., SYKES, A.R. (2004): The effects of cold exposure, food allowance and litter size on immunity of periparturient sheep to Teladorsagia circumcincta and Trichostrongylus colubriformis. Anim. Sci., 78(1): 149 - 158. DOI: 10.1017/s1357729800053935 YazWINSKI, T.A., Goode, L., Moncol, D.J., Morgan, G.W., Linnerud, A.C. (1981): Haemonchus contortus resistance in straightbred and crossbred Barbados Blackbelly sheep. J. Anim. Sci., 51(2): 279 - 284. DOI: 10.2527/jas1980.512279x

Zaragoza-Vera, C.V., Agullar-Caballero, A.J., González-Garduño, R., Arjona-Jiménez, G., Zaragoza-Vera, M., Torres-Acosta, J.F.J.,
Medina-Reynés, J.U., Berumen-Alatorre, A.C. (2019): Variation in phenotypic resistance to gastrointestinal nematodes in hair sheep in the humid tropics of Mexico. Parasitol. Res., 118(2): 567 - 573. DOI: 10.1007/s00436-018-06201-w

Zárate Frutos, R., Pedrozo Prieto, R., Acosta González, R., Lara Nuñez, M., Báez Escalante, M., González Castro, A. (2014): Estudio de perfiles metabólicos en ovinos de la raza Texel en los periodos preservicio, gestación y posparto [Metabolic profiles in Texel sheep in preservice, last third of gestation and early lactation periods]. Compendio Cienc. Vet., 4(2): 39 - 46. Available in: https://www.researchgate.net/publication/282253149\%0AESTUDIO (In Spanish)

Zvinorova, P.I., Halimani, T.E., Muchadeyl, F.C., Matika, O., Riggio, V., DzamA, K. (2016): Breeding for resistance to gastrointestinal nematodes - the potential in low-input/output small ruminant production systems. Vet. Parasitol., 225: 19 - 28. DOI: 10.1016/j.vetpar.2016.05.015 